\title{
Annual Report on the External Quality Assessment Scheme for Biochemical Genetics in Korea (2014)
}

Soo-Youn Lee ${ }^{1}, \mathrm{Ok} \mathrm{Ja} \mathrm{Ji}^{1}$, Gye Cheol Kwon'2, JongWon Kim ${ }^{1}$, Hyung-Doo Park ${ }^{1}$, Junghan Song, Sang-Guk Lee ${ }^{4}$, YongWha Lee ${ }_{2}^{5}$ Eun Hee Lee ${ }^{6}$, Sail Chun, and Tae Youn Choi ${ }^{\circ}$, as Biochemical Genetics Subcommittee, The Korean Association of External Quality Assessment Service ${ }^{1}$ Department of Laboratory Medicine and Genetics, Samsung Medical Center, Sungkyunkwan University School of Medicine, Seoul; ${ }^{2}$ Department of Laboratory Medicine, Chungnam

National University Hospital, Daejeon; ${ }^{3}$ Department of Laboratory Medicine, Seoul Natinal University Bundang Hospital, Seongnam; ${ }^{4}$ Department of Laboratory Medicine, Severance Hospital, Yonsei University College of Medicine, Seoul; 5 Department of Laboratory Medicine and Genetics, Soonchunhyang University Bucheon Hospital, Soonchunhyang University College of Medicine, Bucheon; ${ }^{6}$ Green Cross Laboratories, Yongin; ${ }^{7}$ Department of Laboratory Medicine, Asan Medical Center, University of Ulsan College of Medicine; ${ }^{8}$ Department of Laboratory Medicine, Soonchunhyang University Hospital, Soonchunhyang University College of Medicine, Seoul, Korea

Corresponding author: Soo-Youn Lee Department of Laboratory Medicine \& Genetics, Samsung Medical Center, Sungkyunkwan University School of Medicine, 81 Irwon-ro, Gangnam-gu, Seoul 135-710, Korea

Tel:+82-2-3410-1834

Fax: +82-2-3410-2719

E-mail: suddenbz@skku.edu
Two trials of external quality assessment (EQA) of conventional newborn screening tests for phenylketonuria, galactosaemia, congenital adrenal hyperplasia, maple syrup urine disease, homocystinuria, and congenital hypothyroidism, as well as newborn screening tests were performed using tandem mass spectrometry in 2014. A total of 39 specimens in the form of dried blood spots were distributed to 16 laboratories and the response rate of these laboratories was $100 \%$. Screening tests for phenylketonuria and congenital hypothyroidism did not meet the accepted performance criteria in some laboratories. The mean, standard deviation, coefficient of variation, median, and cut-offs were evaluated for each analyte in the newborn screening tests. Two trials of EQA for the analyses of methylmalonic acid, vanillylmandelic acid, catecholamines, metanephrines, organic acids, and amino acids were also performed. A well-designed EQA program and continuous education would improve the performance of biochemical genetic testing.

(J Lab Med Qual Assur 2015;37:56-63)

Key Words: External quality assessment, Newborn screening, Tandem mass spectrometry, Biochemical genetics 


\section{Journal of LABORATORY MEDICINE and QUALITY ASSURANCE}

\section{Soo-Youn Lee et al • Quality Assessment of Biochemical Genetics}

\section{서론}

대한임상검사정도관리협회 생화학유전학분과에서는 1997 년도부터 선천성대사질환 선별검사에 대한 신빙도조사사업 을 시작하여 매년 2회의 신빙도조사를 시행해오고 있다. 탠덤 질량분석기(tandem mass spectrometry, $\mathrm{MS} / \mathrm{MS}$ )를 이용 한 광범위 선별검사에 대한 신빙도조사사업은 2004년도에 예 비 신빙도조사를 실시한 이래 2007년도부터 정규항목으로 포 함하여 시행 중이다[1]. 2011년도부터는 예비 신빙도조사를 거쳐 소변 메틸말론산(methylmalonic acid, MMA)와 바닐만 델산(vanillylmandelic acid, VMA), 소변 유기산 분석을 추가 하였고, 2012년도부터는 혈장 아미노산 및 유기산 종목을 추 가하였으며, 2014년도에는 요중 카테콜라민, 메타네프린 종목 을 추가하는 등 점차 사업대상종목을 확대해오고 있다[2-4]. 저자들은 2014년 실시된 생화학유전학분과 신빙도조사결과를 분석하여 보고하고자 한다.

\section{재료 및 방법}

\section{1. 대상 및 검체}

2014년도 2회의 생화학유전학분과 선천성대사이상검사 신 빙도조사대상항목 및 정도관리 검체 현황은 Table 1에 정리하 였다. 정도관리 검체는 상품화된 정도관리물질과 자가제조 검 체를 혼용하였고, 항목별 정상과 비정상 수치가 모두 포함되도
록 하였으며, 일부 검체에 대해서는 특정 대사질환에 특이적인 성분 다수를 동시에 포함시켰다.

기본 선별검사의 대상질환으로는 페닐케톤뇨증(phenylketonuria, PKU), 갈락토스혈증(galactosemia), 선천성 부신과형성증(congenital adrenal hyperplasia), 단풍당 뇨증(maple syrup urine disease, MSUD), 호모시스틴 뇨증(homocystinuria, $\mathrm{HCY}$ ), 선천성갑상선기능저하증 (congenital hypothyroidism) 등 6가지가 포함되었으며, 총 16 기관을 대상으로 총 39개(NST13-1-01-10, TMS13-1-0106, NST13-2-01-10, TMS13-2-01-06)의 건조혈액여과지 (dried blood spot, DBS) 검체를 발송하였다. MS/MS를 이 용한 광범위 선별검사항목으로 아실카르니틴(acylcarnitine, $\mathrm{AC}$ )은 1 차와 2 차에 각각 14 종목이 포함되었고, 아미노산은 11 종목이 포함되었다. $\mathrm{DBS}$ 정도관리 검체는 대부분 자가제 조하여 준비하였고, 질환양성 검체를 구하기 어려운 경우 상 품화된 정도관리물질(Bio-Rad Laboratories, Hercules, CA, USA)을 일부 사용하였다. DBS 자가제조를 위해 HIV항체와 $\mathrm{B}$ 형간염 항원이 음성인 혼합혈청에 식염수로 세척한 $\mathrm{O}$ 형 적 혈구 적당량을 첨가하여 헤마토크릿을 약 $55 \%$ 가 되도록 맞춘 전혈을 준비한 후 측정대상 성분을 첨가하였다. 이를 여과지에 $75 \mu \mathrm{L}$ 씩 분주하여 $\mathrm{DBS}$ 를 만든 다음 실온의 암실에서 충분히 말린 후 보관하였다.

아미노산, 유기산 검사를 위한 정도관리 검체는 혼합 혈 청(pooled serum) 또는 혼합 소변(pooled urine)에 상품화

Table 1. Test items and specimens included in the proficiency tests in 2014

\begin{tabular}{|c|c|c|c|}
\hline Test items & Category & Specimen & Number \\
\hline \multicolumn{4}{|l|}{ Neonatal screening } \\
\hline \multirow[t]{6}{*}{ Conventional } & Phenylketonuria & Dried blood spot & 24 \\
\hline & Congenital hypothyroidism (thyroid-stimulating hormone, total T4, or free T4) & & 15 \\
\hline & Galactosaemia & & 24 \\
\hline & Congenital adrenal hyperplasia (17-hydroxyprogesterone) & & 24 \\
\hline & Maple syrup urine disease & & 24 \\
\hline & Homocystinuria & & 24 \\
\hline Expanded & About 40 inherited metabolic disorders (13 amino acids, 18 acylcarnitines) & Dried blood spot & 24 \\
\hline \multicolumn{4}{|l|}{ Other items } \\
\hline Vanillylmandelic acid & & Urine & 6 \\
\hline Methylmalonic acid & & Urine & 6 \\
\hline Organic acids & About 70 organic acids & Urine & 4 \\
\hline Amino acids & About 40 amino acids & Plasma & 4 \\
\hline Catecholamines & Dopamine, epinephrine, norepinephrine & Urine & 6 \\
\hline Metanephrines & Metanephrine, normetanephrine & Urine & 6 \\
\hline
\end{tabular}


된 표준물질(Sigma-Aldrich, St. Louis, MO, USA)을 첨 가하여 제조하였다. $\mathrm{MMA}$ 검사를 위해서는 정상 성인의 혼 합 소변에 $\mathrm{MMA}$ 표준물질을 첨가하여 $\mathrm{MMA}$ 고농도인 검체 (MMA14-1-01-03, MMA14-2-01-03)를 제조하였다. VMA 정도관리 검체(VMA14-1-01-03, VMA14-2-01-03)는 요 중 $\mathrm{VMA}$ 수치가 높은 환자들의 혼합 소변을 이용하여 준비 하였다. 유기산검사를 위한 소변 검체(organic acid 14-1-0102, organic acid 14-2-01-02)도 정상 성인의 혼합 소변에 각 표준물질(Sigma-Aldrich)을 첨가하여 제조하였다. 1차에 $\mathrm{N}$-acetylaspartic acid, ethylmalonic acid, methylsuccinic acid, 3-hydroxybutyric acid 표준물질을 첨가하였고, 2차 에 glutaric acid, ethylmalonic acid, fumaric acid, succinic acid, citric acid, malic acid, 2-ketoglutaric acid 표준물질 을 첨가하였다. 혈장 아미노산 분석(amino acid 14-1-01-02, amino acid 14-2-01-02)을 위해서는 정상 성인의 혼합 혈장 (pooled plasma)에 proline, alanine, citrulline, glutamic acid, histidine, glycine 표준물질(Sigma-Aldrich)을 첨가한 혈장 검체를 제조하여 발송하였다.

2014년도부터 새로이 시작된 카테콜라민과 메타네프린 종목을 위한 검체(CATE14-1-01-03, META14-1-01-03, CATE14-2-01-03, META14-2-01-03)들은 환자들의 혼합 소 변을 이용하여 제조하였다.

\section{2. 결과 판정 및 분석}

기본 선별검사의 경우에는 각 검사기관이 수행하고 있는 종 목에 대해 검사를 실시하여 결과수치와 함께 정상 및 비정상, 재검 여부 등을 판정하여 회신하도록 하였다. 결과분석 시 같 은 검사방법을 이용한 응답기관이 3개 이상일 경우에 평균, 표 준편차, 변이계수를 구하였다. 또한 검사결과로부터 각 검사 기관에서 판독하는 정상 및 비정상, 재검 여부의 판정결과에 대해 분석하였다. MS/MS를 이용한 광범위 선별검사의 경우 $\mathrm{AC}$ 및 아미노산 결과수치와 함께 정상 및 비정상 판정, 기준 치(cut-off) 등을 회신하도록 하였다. 결과분석은 응답기관에 대해 판정결과 및 판정일치율과 각 기관에서 사용하고 있는 기 준치에 대한 평균, 중앙값, 최젓값, 최곳값에 대해 분석하였고, 각 기관의 검사성적에 대한 비교 평가 그래프를 제공하였다.

$\mathrm{MMA}$ 및 VMA검사의 경우는 참여기관 수가 많지 않아 보 고된 수치들의 범위를 제공하는 것으로 결과 판정을 대신하였 으며, 측정값의 평균, 중앙값, 최젓값, 최곳값에 대해 분석한 표를 제공하였다. 유기산, 아미노산 및 초장사슬지방산검사 역 시 소수의 기관만 검사를 수행하므로 측정값을 비교할 수 있도 록 각 기관이 보고한 항목과 측정값을 제공하는 것으로 결과
판정을 대신하였다. 수탁기관에 대한 정도관리인증기준은 참 가기관 수 5 개 이상이면서 결과판정일치율이 $70 \%$ 이상인 기 본선별검사종목을 대상으로, 종목별 보고결과의 정답 일치율 $80 \%$ 이상, 참가한 종목 전체 보고결과의 정답일치율 $90 \%$ 이 상인 경우로 하였다.

\section{결과}

\section{1. 참여기관 및 회신율}

2001년부터 2014년도까지의 연도별 참여기관 및 회신율은 Fig. 1과 같았다. 2014년도 1차와 2차 신빙도조사에서의 전체 16 기관의 회신율은 $100 \%$ 로 각 기관에서 실제로 시행하고 있 는 검사들에 대해 모두 신빙도조사에 참가 및 회신하였다. 기 본 선별검사 6항목은 총 14 기관, $\mathrm{MS} / \mathrm{MS}$ 를 이용한 광범위 선 별검사항목에 대해서는 해당 검사 시행 중인 총 15 기관이 해 당하였다. $\mathrm{MMA}$ 검사 4기관, $\mathrm{VMA}$ 검사 7기관, 아미노산검사6 기관, 유기산검사 5 기관이 각각 참여하였다. 카테콜라민과 메 타네프린 종목에 대해서는 총 6 개의 소변 검체를 발송하였는 데, 각각 3 개, 6 개의 기관이 참여하였다.

\section{2. 검사법 및 장비현황}

6 개 질환에 대한 기본 신생아 선별검사에 이용되는 검사방 법은 Fig. 2와 같았다. 기본 선별검사에는 효소비색법, 효소면 역측정법, 방사선면역측정법과 $\mathrm{MS} / \mathrm{MS}$ 법 등이 이용되어 왔

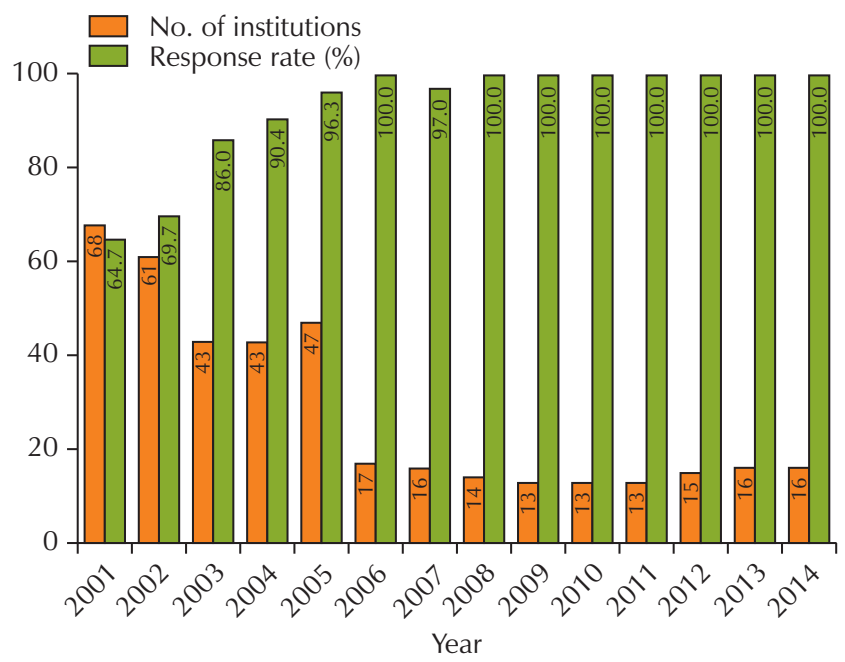

Fig. 1. The number of institutions that participated in the program conducted by the Korean Association of Quality Assurance for newborn screening tests and their corresponding response rates (2001-2014). 


\section{Journal of LABORATORY MEDICINE and QUALITY ASSURANCE}

\section{Soo-Youn Lee et al • Quality Assessment of Biochemical Genetics}

는데, MSUD, PKU, HCY 선별검사의 경우 면역분석법 대신 $\mathrm{MS} / \mathrm{MS}$ 법을 사용하는 기관 수가 해마다 증가하여, 2014년 신 빙도조사에서는 총 16 기관 중 15 기관에서 $\mathrm{MS} / \mathrm{MS}$ 법을 사용 하여 결과를 보고하였다. VMA, MMA, 유기산검사에는 가 스크로마토그래피-질량분석법(gas chromatography-mass spectrometry)법이 이용되었으며, 아미노산분석에는 액체 크로마토그래피-탠덤질량분석법(liquid chromatography-

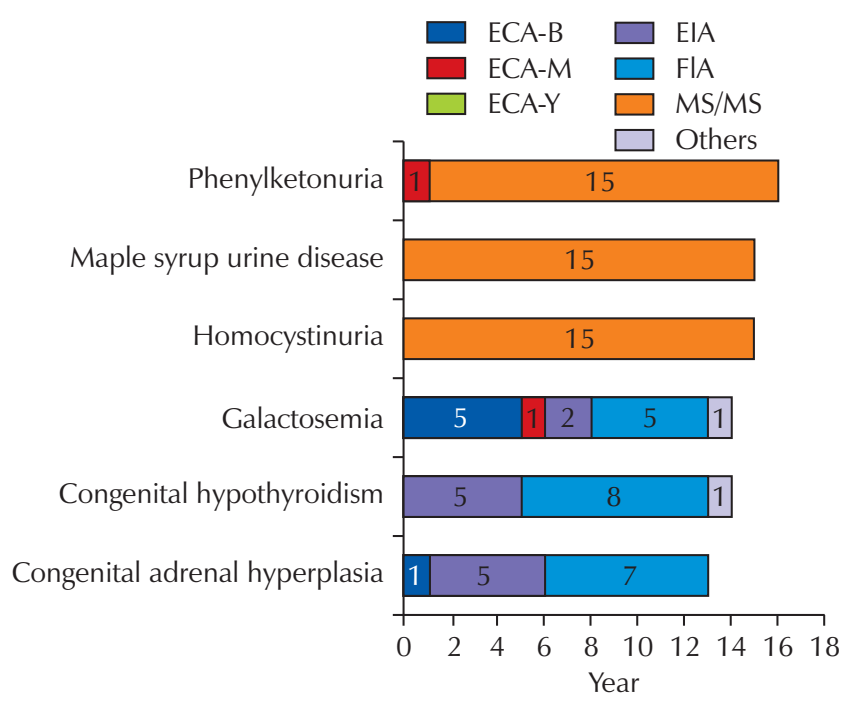

Fig. 2. The analytical methods used for conventional neonatal screening tests in 2013. Abbreviations: ECA-B, enzyme colorimetric assay using a Bio-Rad kit; ECA-M: enzyme colorimetric assay using a MP Biomedicals kit; ECA-Y, enzyme colorimetric assay using a Bayer kit; EIA, enzyme immunoassay using a Bio-Rad kit; FIA, fluorometric immunoassay using a Perkin-Elmer kit; MS/MS, tandem mass spectrometry. tandem mass spectrometry)이 이용되었다. 카테콜라민과 메 타네프린 검사에는 액체크로마토그래피 또는 액체크로마토그 래피-탠덤질량분석법이 이용되었다.

\section{3. 신빙도조사결과}

6종 기본 선별검사와 $\mathrm{MS} / \mathrm{MS}$ 를 이용한 광범위 신생아선별 검사 및 각 항목별 정답률 현황은 Tables 2,3 에 정리하였다. $\mathrm{MS} / \mathrm{MS}$ 검사상 포함된 각 항목에 대한 기준치의 분포는Table 4 와 같았다.

신생아 선별검사에 대한 상세 자료는 Supplementary Tables 1-16에 정리된 내용을 참조하기 바란다. MMA 및 VMA에 대한 결과는 Supplementary Tables 17, 18, 유기산 분석결과는 Supplementary Tables 19, 20, 아미노산 분석결 과는 Supplementary Tables 21, 22, 카테콜라민과 메타네프 린 분석결과는 Supplementary Tables 23, 24에 제시하였다.

\section{고찰}

생화학유전학분과 신빙도조사사업은 1997년에 처음 시행 되었으며 1998년에 1회, 1999년 2회, 2000년에 2회, 2001년 1 회 시행하였고 2002년도부터는 매년 2회씩 시행하고 있다. $\mathrm{MS} / \mathrm{MS}$ 를 이용한 광범위 선별검사에 대한 신빙도조사사업은 2007년도부터 시작하였고, 2011년도부터는 아미노산, 유기산, $\mathrm{MMA}, \mathrm{VMA}$ 등을 포함하여 종목 확대를 위해 노력하고 있다. 정도관리 검체는 상품화된 정도관리 검체와 자가제조 검체를 혼용하여 사용하였으며 정상과 비정상 수치가 모두 포함되도 록 하고 있다.

2014년도에는 항목별 검체의 수를 증가시키고 cut-off보다 약간 높은 수치를 보이는 검체를 포함시켜 신빙도조사를 통한

Table 2. Results of the proficiency testing of conventional neonatal screening tests

\begin{tabular}{|c|c|c|c|c|}
\hline \multirow[b]{2}{*}{ Variable } & \multicolumn{2}{|c|}{ 1st trial } & \multicolumn{2}{|c|}{ 2nd trial } \\
\hline & $\begin{array}{c}\text { No. of } \\
\text { institutions }\end{array}$ & $\begin{array}{c}\text { Proportion of } \\
\text { correct answers (\%) }\end{array}$ & $\begin{array}{c}\text { No. of } \\
\text { institutions }\end{array}$ & $\begin{array}{c}\text { Proportion of } \\
\text { correct answers (\%) }\end{array}$ \\
\hline Phenylketonuria & 16 & 190/191 (99) & 16 & $163 / 176(93)$ \\
\hline Galactosaemia & 14 & $168 / 168(100)$ & 15 & $180 / 180(100)$ \\
\hline Congenital adrenal hyperplasia & 13 & $151 / 152(99)$ & 14 & $168 / 168(100)$ \\
\hline Maple syrup urine disease & 15 & $180 / 180(100)$ & 15 & $167 / 168(99)$ \\
\hline Homocystinuria & 15 & $176 / 179(98)$ & 15 & $180 / 180(100)$ \\
\hline \multicolumn{5}{|l|}{ Congenital hypothyroidism } \\
\hline Thyroid-stimulating hormone & 14 & $83 / 83(100)$ & 15 & $135 / 135(100)$ \\
\hline T4, total & 6 & $29 / 29(100)$ & 7 & $63 / 63(100)$ \\
\hline $\mathrm{T} 4$, free & 8 & $20 / 21(95)$ & 7 & $57 / 63(90)$ \\
\hline
\end{tabular}


Journal of LABORATORY MEDICINE and QUALITY ASSURANCE

Soo-Youn Lee et al • Quality Assessment of Biochemical Genetics

Table 3. Results of the proficiency testing of expanded neonatal screening tests using tandem mass spectrometry

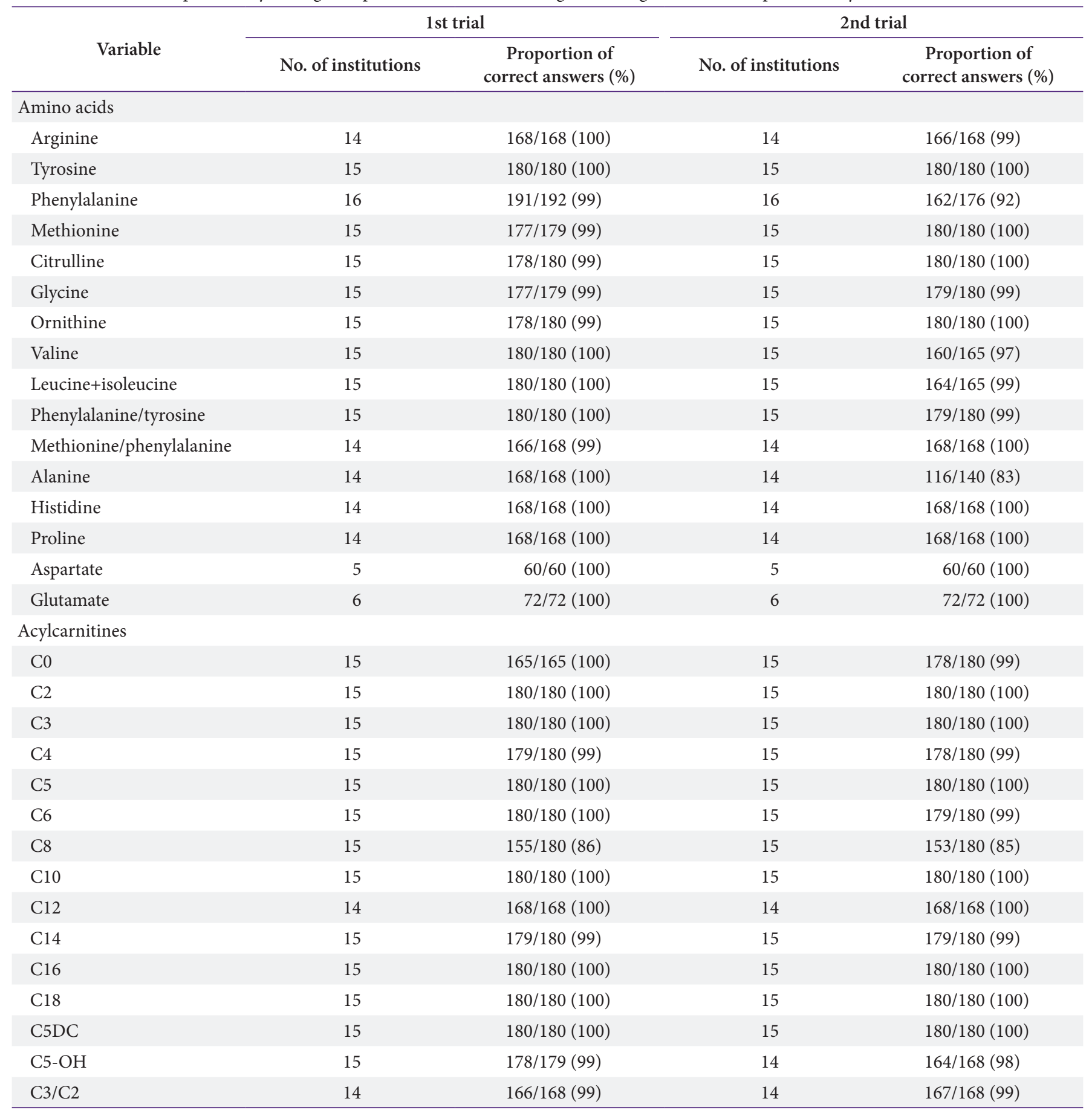

각 기관의 검사수행능을 보다 정확히 파악하는 데 도움을 주고 자 하였다. 그 결과 판정의 불일치를 보인 항목들이 일부 항목 들에서 또는 일부 기관에서 발견되었다. 페닐케톤뇨증의 경우 특정 기관에서만 여러 검체에 대해 판정 불일치를 보였는데, 타 기관에 비해 cut-off가 상당히 다르게 설정되어 있는 것으
로 나타나 cut-off 재검토를 권유하였다. 호모시스틴뇨증과 선 천성 갑상선기능저하증의 경우도 판정 불일치를 보인 기관들 은 검사결과 수치는 타 기관과 별로 차이가 없으면서 cut-off가 타 기관에 비해 유의하게 다른 것으로 나타났다. T4나 thyroid stimulating hormone 항목의 경우에는 다양한 종류의 정도관 
Journal of LABORATORY MEDICINE and QUALITY ASSURANCE

Soo-Youn Lee et al $\bullet$ Quality Assessment of Biochemical Genetics

Table 4. Cut-offs used in expanded neonatal screening tests using tandem mass spectrometry

\begin{tabular}{|c|c|c|c|c|}
\hline Variable & Mean & Median & Minimum & Maximum \\
\hline Arginine & 55.47 & 58.95 & 29.7 & 73.7 \\
\hline Tyrosine & 289.37 & 299.35 & 206.3 & 402 \\
\hline Phenylalanine & 122.77 & 123 & 92 & 150 \\
\hline Methionine & 61.67 & 60 & 38 & 86.5 \\
\hline Glycine & 988.24 & 1,000 & 442.53 & $1,604.01$ \\
\hline Ornithine & 297.15 & 287 & 175 & 488 \\
\hline Valine & 273 & 267.28 & 210.59 & 361.23 \\
\hline Leucine+isoleucine & 296.81 & 300 & 222 & 351.4 \\
\hline Histidine & 223 & 174 & 1.46 & 910.18 \\
\hline Proline & 424.75 & 365.9 & 5.52 & 1523 \\
\hline Aspartate & 258.58 & 163.1 & 150 & 644.82 \\
\hline Glutamate & 713.98 & 720.05 & 563 & 850 \\
\hline \multicolumn{5}{|l|}{ Acylcarnitines $(\mu \mathrm{mol} / \mathrm{L})$} \\
\hline $\mathrm{C} 0$ & 67.75 & 63.46 & 50 & 95.7 \\
\hline $\mathrm{C} 2$ & 53.65 & 50 & 39.5 & 80 \\
\hline $\mathrm{C} 3$ & 5.01 & 5.01 & 3.59 & 7.18 \\
\hline $\mathrm{C} 12$ & 0.46 & 0.43 & 0.26 & 0.8 \\
\hline $\mathrm{C} 14$ & 0.67 & 0.74 & 0.38 & 0.9 \\
\hline $\mathrm{C} 16$ & 6.67 & 6.48 & 4.38 & 9.69 \\
\hline $\mathrm{C} 18$ & 1.96 & 1.96 & 0.67 & 4.23 \\
\hline C5DC & 0.25 & 0.26 & 0.14 & 0.35 \\
\hline $\mathrm{C} 5-\mathrm{OH}$ & 0.58 & 0.6 & 0.44 & 0.8 \\
\hline $\mathrm{C} 3 / \mathrm{C} 2$ & 0.26 & 0.29 & 0.1 & 0.38 \\
\hline
\end{tabular}

리물질 확보가 힘들며 기관별 검사방법이 달라 항상 어려움을 겪는데, 특히 기준치에 인접한 측정값을 나타내는 항목들은 결 과판정 일치율이 $70 \%$ 미만으로 낮아 판정 보류를 한 항목들 이 있었다. 이러한 검체들에 대한 분석결과들에 대해서는 기관 별 측정값, 측정방법, 기준치의 차이와 그에 따른 판정결과의 차이, 재검률에 대해 각 기관 자체적으로 면밀한 고찰이 필요
하깄다.

$\mathrm{MS} / \mathrm{MS}$ 를 이용한 광범위선별검사에서도 일부 종목에서 판 정 불일치가 관찰되었으며, 이들 기관에서는 기관 내 cut-off 및 검사방법에 대한 검토가 필요할 것으로 판단되었다. $\mathrm{C} 8$, alanine, tyrosine, ornithine 등의 종목에 대해서도 판정 불 일치를 보인 기관들은 cut-off가 타 기관에 비해 유의하게 다 
른 것으로 나타났다. 특히 $\mathrm{C} 8$ 의 경우 특정 기관에서 정상인 검 체들 다수에 대해 모두 비정상으로 보고하기도 하였다. 또한 $\mathrm{MS} / \mathrm{MS}$ 검사에서 일부 항목들에 대하여 보고하지 않는 기관 의 경우 자체적인 검토를 통하여 보고 항목으로 추가를 검토할 것이 권장된다.

유기산검사는 1차와 2 차에서 각 2검체를 발송하였으며, 모 든 기관이 질환명과 cut-off 이상의 증가를 보이는 유기산들을 보고하였으나, 그 상승 정도는 기관별로 큰 차이를 보였고 증 가한 것으로 보고한 성분이 다소 차이를 보이는 경우도 있었 다. 해당 대사이상질환에 대한 전형적인 양상을 보이는 검체에 대해서는 각 기관에서 보고한 진단명이 대부분 일치하였으나 일부 기관에서 중요한 성분이 검출되지 않아 진단을 하지 못한 경우도 있었다.

아미노산검사는 1 차 및 2 차 각각 2 검체를 발송하였으며, 각 기관이 제출한 측정값을 제시하는 것으로 평가를 대신하였다. 모든 기관이 유의한 증가를 보이는 아미노산들과 합당한 질환 명을 보고하였으나 그 상승 정도는 기관별로 차이를 보였다.

$\mathrm{MMA}, \mathrm{VMA}$ 항목의 경우 예년과 마찬가지로 참여한 모든 기관에서 유사한 측정결과값을 보고하였다. 2014년도 처음으 로 시행한 catecholamine, metanephrine항목에 대해서는 총 7개 기관에서 신빙도조사에 참여하였으며, 응답한 모든 기관 에서 유사한 측정결과값을 보고하였다.

선천성대사질환에 대한 신생아선별검사는 검사수치뿐 아니 라 결과에 대한 정상 및 비정상에 대한 적절한 판독이 매우 중 요하다. 그러나 각 기관에서 검사에 사용하는 시약과 검사방법 이 다양하고 정상 및 비정상을 평가할 기준치가 서로 다른 경 우가 많았다. 또한 생화학유전학분과 신빙도조사에서 겪는 애 로사항으로 동일검사법 이용기관의 수가 적은 경우 비교 불가 한 점, 다양한 질환 양성 검체를 대량 확보하기 어려운 점, 단 일 성분만이 아닌 다수의 증감 양상이 조합된 검체를 준비해야 하는 점 등이 있었다. 각 기관에서는 신빙도조사결과를 자체적 으로도 면밀히 검토 분석하여 분석법의 신뢰성을 확인하고 내 부정도관리를 강화함과 동시에 주기적으로 기준치를 검증하 고 결과보고종목 및 결과해석의 차이도 점검해보는 것이 매우 중요할 것으로 생각된다. 앞으로도 종목 확대, 적절한 정도관 리물질의 확보, 워크숍 개최를 통한 관련 인력교육을 포함하여 지속적으로 신빙도조사 프로그램을 개선 · 발전시킬 수 있는 방향을 모색한다면 생화학유전검사의 질 향상에 기여할 수 있 을 것으로 전망한다.

\section{감사의 글}

정도관리물질 제조관리와 결과자료분석 등 본 신빙도조사를 위해 수고해주신 삼성서울병원 진단검사의학과 특수화학검사 실 직원 여러분들과 전공의 및 임상강사 선생님께 감사드린다.

\section{생화학유전분과위원회 위원(2014)}

이수연(위원장, 성균관대학교 의과대학), 지옥자(간사, 삼성 서울병원), 권계철(충남대학교 의과대학), 김종원(성균관대학 교 의과대학), 박형두(성균관대학교 의과대학), 송정한(서울 대학교 의과대학), 이상국(연세대학교 의과대학), 이용화(순 천향대학교 의과대학), 이은희(녹십자의료재단), 전사일(울산 대학교 의과대학), 최태윤(순천향대학교 의과대학)

\section{SUPPLEMENTARY MATERIALS}

Supplementary materials can be found via http:// pdf.medrang.co.kr/LMQA/2015/037/LMQA037-02-02 Supple1.pdf

\section{REFERENCES}

1. Song J, Kwon KC, Kim JH, Kim JW, Min WK, Lee SY, et al. Annual report on external quality assessment in metabolic disorders in Korea (2007). J Lab Med Qual Assur 2008;30:151-66.

2. Lee SY, Kwon KC, Kim JH, Kim JW, Park BT, Park HD, et al. Annual report on external quality assessment in biochemical genetics in Korea (2011). J Lab Med Qual Assur 2012;34:S25-49.

3. Lee SY, Kwon KC, Kim JH, Kim JW, Park BT, Park HD, et al. Annual report on external quality assessment in biochemical genetics in Korea (2012). J Lab Med Qual Assur 2013;35:S29-63.

4. Lee SY; Biochemical Genetics Subcommittee, The Korean Association of Quality Assurance for Clinical Laboratory. Annual report on external quality assessment of biochemical genetics in Korea (2013). J Lab Med Qual Assur 2014;36:64-70. 
생화학유전분과 신빙도조사 결과보고(2014)

이수연 ${ }^{1}$ 지옥자 ${ }^{1} \bullet$ 권계철 $^{2}$ - 김종원 ${ }^{1} \bullet$ 박형두 $^{1}$ - 송정한 ${ }^{3} \bullet$ 이상국 $^{4}$

이용화 ${ }^{5}$ - 이은희 ${ }^{6}$ - 전사일 ${ }^{7}$ 최태윤 ${ }^{8}$ - 대한임상검사정도관리협회 생화학유 전분과위원회

${ }^{1}$ 성균관대학교 의과대학 삼성서울병원 진단검사의학과, ${ }^{2}$ 충남대학교병원 진단검사의학과, ${ }^{3}$ 분당서울대학 교병원 진단검사의학과, ${ }^{4}$ 연세대학교 의과대학 세브란스병원 진단검사의학과, ${ }^{5}$ 순천향대학교 의과대학 순 천향대학교 부천병원 진단검사의학과, ${ }^{6}$ 녹십자의료재단, ${ }^{7}$ 울산대학교 의과대학 서울아산병원 진단검사의 학과, ${ }^{8}$ 순천향대학교 의과대학 순천향대학교 서울병원 진단검사의학과

2014년도 생화학유전학분과 신빙도조사사업은 총 2회 시행되었다. 페닐케톤뇨증, 갈락토오스혈증, 선천성 부신형성과다증, 단풍당뇨증, 호모시스틴뇨증, 선천성 갑상선기능저하증을 포함하는 선천성 대사질환 기본 선별검사와 탠덤질량분석기를 이용한 광범위 선별검사를 위한 총 32개의 건조혈액여 과지 검체를 16 기관에 발송하였다. 회신율은 $100 \%$ 로, 타 기관으로 위탁을 보내는 검사항목은 제외 하고 각 기관에서 실제로 시행하고 있는 검사들은 모두 참가하였다. 특히 기준치에 인접한 값을 보이 는 검체들이 포함되어 결과판정 일치율이 $70 \%$ 미만으로 낮아 판정 보류를 한 항목들이 관찰되었다. 타 기관과 차이 나는 측정값 또는 판정을 보이는 경우에는 기관별 측정값, 측정방법, 기준치의 차이와 그에 따른 판정결과의 차이나 결과해석방법 등에 대해 각 기관별로 면밀한 자체 검토가 필요할 것으 로 판단되었다. 이외 메틸말론산과 바닐만델산, 유기산, 아미노산, 카테콜라민 및 메타네프린 항목에 대한 신빙도조사도 시행되었으며 대부분 만족스러운 결과를 보였다. 외부정도관리 프로그램과 지속 적인 교육을 통하여 생화학유전검사의 질을 향상시킬 수 있을 것으로 기대된다.

(J Lab Med Qual Assur 2015;37:56-63)

교신저자: 이수연

우)135-710 서울시 강남구 일원로 81, 성균관대학교 의과대학 삼성서울병원 진단검사의학과

Tel: 02)3410-1834, Fax: 02)3410-2719, E-mail: suddenbz@skku.edu 